\title{
A VARIANT OF ORGANIZING A WIRELESS NETWORK FOR TRANSMITTING PHYSIOLOGICAL INDICATORS OF THE PILOT'S HEALTH ON BOARD AIRCRAFT BASED ON MIDLLE INFRARED BAND LASER RADIATION
}

DOI: 10.36724/2072-8735-2020-14-4-47-56

\author{
Dmitry S. Koptev, \\ Federal State Budgetary Educational Institution \\ of Higher Education "Southwest State University" \\ (FSBEI of Higher Education "SWSU"), Kursk, Russia, \\ d.s.koptev@mail.ru
}

\begin{abstract}
Keywords: medical operational monitoring, physiological indicators of the pilot's health, wireless data transmission, optical radiation, ultra-wideband signal, electromagnetic interference, interference immunity, semiconductor laser, signal spectrum
\end{abstract}

\begin{abstract}
According to the strategy for aircraft industry development up until 2023, the main efforts of the aviation industry are aimed at creating high-speed and maneuverable aircraft by means of increasing the power of propulsion units, implementing complex flight control systems, navigation, and improving the details of technical equipment [I]. However, the physiological capabilities of an aircraft operator (pilot) are beginning to lag behind the technological capabilities of state-of-the-art aircraft technology in terms of effective and operational management of it, carrying out military tasks and significant overload capacity. More than $\mathbf{7 0} \%$ of aviation accidents are related to the flight activity of crews, a third of which is caused by breakdown of the functional status of a pilot due to the impact of extreme flight factors. The system of medical operational monitoring (SMOM) is designed to register physiological indicators of the pilot's health.

The goal of the present paper is to develop a variant of organizing a wireless network for transmitting data about the physiological status of a pilot on board aircraft in a high interference signaling environment. The research methods are based upon a sequential analysis of the mechanisms of wireless technologies operation for transmitting data over short distances (Bluetooth (IEEE 802.15.I), UWB (IEEE 802.15.4 z), IrDA), using various principles of information exchange (frequency range, signal-code structures, level of radiated power). Evaluating the possibility of using a particular technology was carried out in order to ensure correct operation directly during the flight on board aircraft affected by electromagnetic interference, noise, vibrations, and interference from devices operating in the adjacent frequency range. We used common methods of spectral analysis of signals, as well as the methods for evaluating the potential interference immunity of optical radiation reception.

Results. A variant of the wireless network for transmitting physiological indicators of the pilot's health based on middle infrared band laser radiation has been developed in the given paper. The source of radiation used is a semiconductor laser based on the InGaAsP heterostructure with monochromatic emission at a wavelength of $\mathrm{I} .55$ micrometers, high- power output of optical radiation, and narrow (I-3 nm) spectral band width, which minimizes the influence of interference from natural and artificial light sources on the transmitted optical signal. The choice of emission wavelength is due to the lower amount of scattering and absorption, as well as safety for the operator's eyes. The emission direction is maintained by equipping the laser with a thin spreading lens that increases the area of possible reception. The elimination of side emission is carried out using a multi - layer interference filter made of GaSb gallium antimonide films which has a high refractive index, high wear resistance, and narrow bandwidth (1.25-2.1 micrometers). The evaluation of interference immunity of wireless optical transmission line being carried out in the final part of the paper has shown that the use of such a filter does allow one to increase a signal-to-noise ratio at the input of photodiode.
\end{abstract}

Information about authors:

Dmitry S. Koptev, post-graduate student, Federal State Budgetary Educational Institution of Higher Education "Southwest State University" (FSBEI of Higher Education "SWSU"), Kursk, Russia

Для цитирования:

Коптев Д.С. Вариант организации беспроводной сети передачи физиологических показателей здоровья пилота на борту воздушного судна на основе лазерного излучения среднего инфракрасного диапазона // Т-Comm: Телекоммуникации и транспорт. 2020. Том 14. №4. C. 47-56.

For citation:

Koptev D.S. (2020) A variant of organizing a wireless network for transmitting physiological indicators of the pilot's health on board aircraft based on midlle infrared band laser radiation. T-Comm, vol. 14, no.4, pp. 47-56. (in Russian) 


\section{ELECTRONICS. RADIO ENGINEERING}

\section{Introduction}

The problem of ensuring the safety of aircraft operations is one of the most important issues on the agenda of International Civil Aviation Organization (ICAO). One of the most important activities of this organization is the development of theoretical methods and technical tools and systems that monitor the functional status of a pilot.

The system of medical operational monitoring is designed to register physiological indicators of the pilot's health directly in the process of performing operators' activities (during the flight). This system uses a pulse oximetry module of the "clip" type to collect and transmit primary physiological information via a wired interface, and then, with the help of a physiological indicators processing unit, converts primary signals and calculates the values of physiological health indicators, such as: pulse rate (PE), blood saturation level $\left(\mathrm{SpO}_{2}\right)$, and respiratory rhythm. The results obtained are transmitted via a wireless communication channel to a data collection unit, where the estimated data is stored in the internal non-volatile memory.

The system includes:

- pulse oximetry module;

- un $\mathrm{t}$ for processing physiological indicators;

- data collection unit [1].

The general schematic and functional diagram of medical operational monitoring system for assessing the functional status of an aircraft pilot is shown in Figure 1.

The goal of the present article is to develop a variant of a wireless data transmission network between the physiological indicators processing unit and the data collection unit. We shall discuss in detail transmission mechanisms, features and characteristics of wireless technologies concerning their use on board aircraft.

\section{Analysis of short-range wireless data transmission technologies for use on board aircraft.}

Bluetooth is a technology for transmitting data over a radio channel over short distances (up to about $10 \mathrm{~m}$ ) that does not require direct visibility between devices [2].

The Bluetooth specification regulates the use of ISM band (2400-2483.5 MHz) with packet data transmission and with time division of channels. The method of Frequency Hopping Spread Spectrum (FHSS) is used, when the entire frequency band available for transmission is divided into a certain number of subchannels (usually 79) with a width of $1 \mathrm{MHz}$ each. The duration of time interval of one channel is 625 microseconds [2].

There are three classes of Bluetooth devices which are graded by the level of radiated power and radio communication range provided in accordance with Table 1.

Features of Bluetooth device classes

Table 1

\begin{tabular}{|c|c|c|}
\hline $\begin{array}{c}\text { Bluetooth device } \\
\text { class }\end{array}$ & $\begin{array}{c}\text { Maximum radiated power, } \\
\mathrm{mW}\end{array}$ & $\begin{array}{c}\text { Radio communica- } \\
\text { tion range, } \mathrm{m}\end{array}$ \\
\hline Class 1 & 100 & up to 100 \\
\hline Class 2 & 2,5 & up to 10 \\
\hline Class 3 & 1 & up to 1 \\
\hline
\end{tabular}

In accordance with time division channeling for arrangement of duplex transmission in the Bluetooth standard, it is assumed that during odd time segments packets are transmitted by the basic transmission unit and during even time segments by the ancillary device (Figure 2).
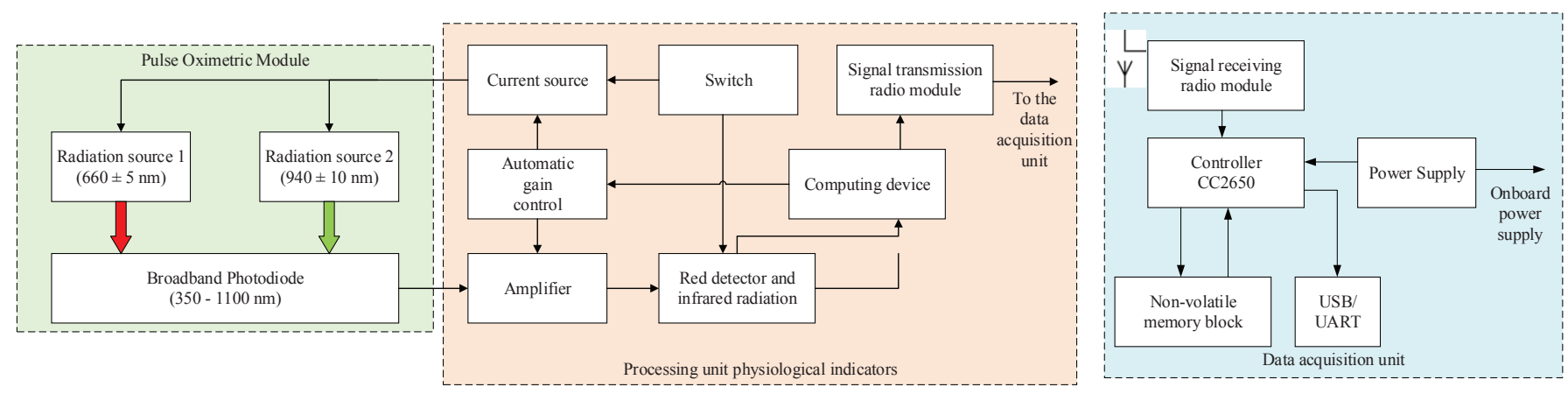

Figure 1. General structural and functional diagram of an operational medical control system for assessing the functional state of an aircraft pilot

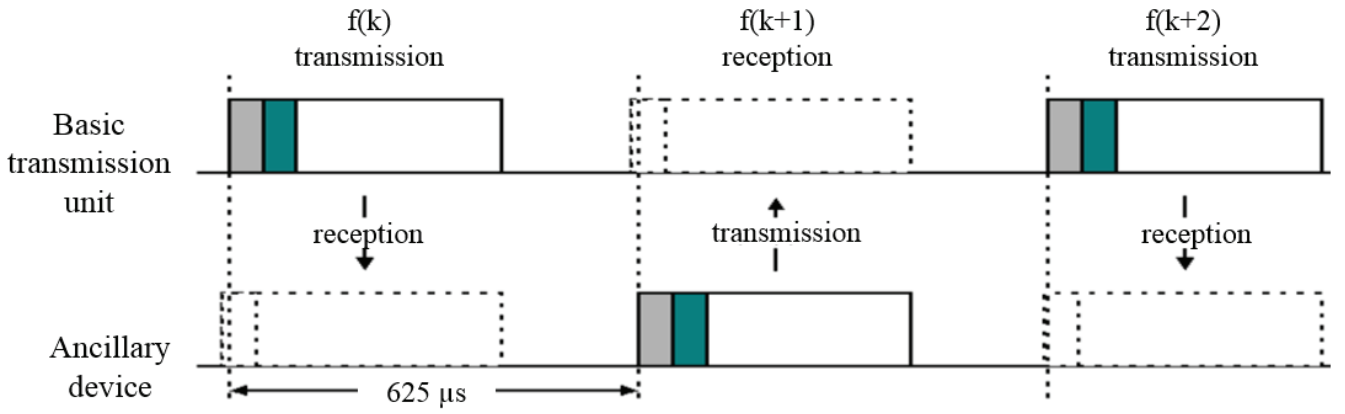

Figure 2. Time division duplex 


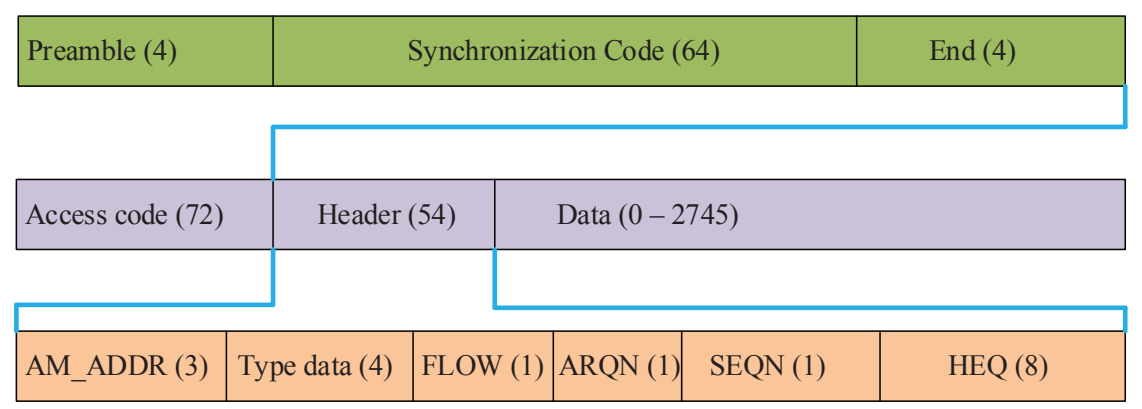

Figure 3. Bluetooth protocol frame format

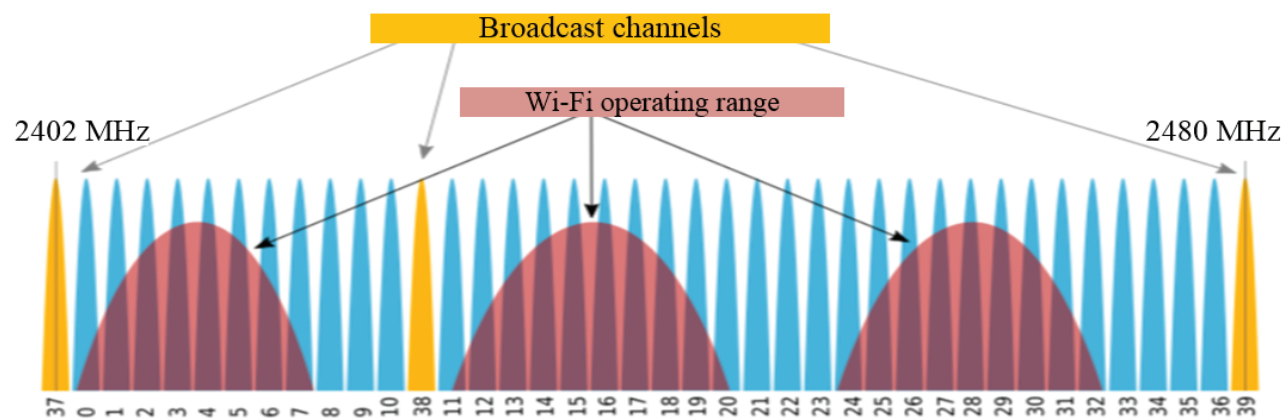

Figure 4. Structure of radio band used in Bluetooth 4.2

Bluetooth packets can consist of either an access code alone (the size is 68 bits) or an access code together with a header. The task of the access code is to identify packets within the same piconet, as well as to organize the synchronization procedure (Figure 3).

The header accumulates information for data exchange and management and has a structure consisting of six fields: the address of an active element (AM_ADDR), data type code, data flow control which shows the unit's preparedness for reception (FLOW), confirmation of correct reception (ARQN), packet sequence detection (SEQN), and checksum (HEC) [3].

Defining a logical channel, controlling the flow in logical channels, and specifying the size of wanted information (0-2721 bits) is performed by the wanted information header which consists of 8 bits. In addition, a 16-bit cyclic redundancy code (CRC) is singled out from the transmitted information. Then, this code is added to the information [3].

Bluetooth 4.2 version uses 40 radio channels with a width of $2 \mathrm{MHz}$ (Figure 4) in contrast to the classic Bluetooth described above.

Only 3 out of the 40 channels are intended for sending broadcast packets: $37(2402 \mathrm{MHz}), 38(2426 \mathrm{MHz})$ and 39 (2480 MHz): first, a packet is transmitted through channel 37, then through 38 and 39, and again through 37, and so on. Packet distribution interval is configured programmatically, usually it is from $20 \mathrm{~ms}$ to $10.24 \mathrm{~s}$.

Data encryption is performed using a AES-CCM cryptographic protocol. The Bluetooth controller generates 128 bits of encrypted data from a 128-bit key and 128 bits of unencrypted data. Such an algorithm is almost impossible to hack and provides a high-quality level of data protection. By means of this, interference immunity of data transmission is provided.
Summarizing all of the above mentioned, we can say that Bluetooth transmission technology, in particular Bluetooth 4.2 version, has the following key features:

- $\quad$ large data packet payload size - up to 251 bytes;

- ultra-low power consumption due to the "slack" mode of operation (the radio transmitter is turned on only at the time of transmission);

- $\quad$ short period of connection setup and break (about $6 \mathrm{~ms}$ );

- $\quad$ small amount of memory required (the protocol stack takes up 90-120 kilobytes of microcontroller flash memory);

there is a 128-bit cryptographic AES protocol. Its keys are protected by the ECDH algorithm during the exchange [4].

However, despite a number of advantages, this technology has the following disadvantages:

- aximum data transfer rate - up to $723 \mathrm{kbit} / \mathrm{s}$ (which may be limited even more, it all depends on the choice of hardware);

- low interference immunity of the technology due to its narrow bandwidth. The energy of the transmitted signal is concentrated in a narrow region of spectrum, which, when exposed to interference, leads to failures in connection setup or distortion of the transmitted information;

- weak resistance to mutual influences.

The key issue in implementing wireless data transfer technologies on board aircraft is ensuring interference immunity and a set level of electromagnetic compatibility. The operation of a huge number of radio and navigation electrified equipment on board aircraft is a source of various types of interference (narrow-band, broadband, pulse, etc.) that affect the optimal traffic of wireless communications. A significant impact on the provision of wireless data exchange directly on board aircraft is caused by factors related to the specifics of aircraft systems operation: the presence of electromagnetic interference, noise, vibration, and mutual interference from devices operating in the same frequency resource or time channel. 
In work [5], a procedure for studying mutual interferences when two Bluetooth systems operate simultaneously on board the aircraft has been described. When providing distance between devices of around 1.0 meter, there were no failures in operation. However, at a distance of less than 0.5 meter, single failures began to occur in the communication channel of the basic unit. The oscillograph chart is shown in Figure 5.

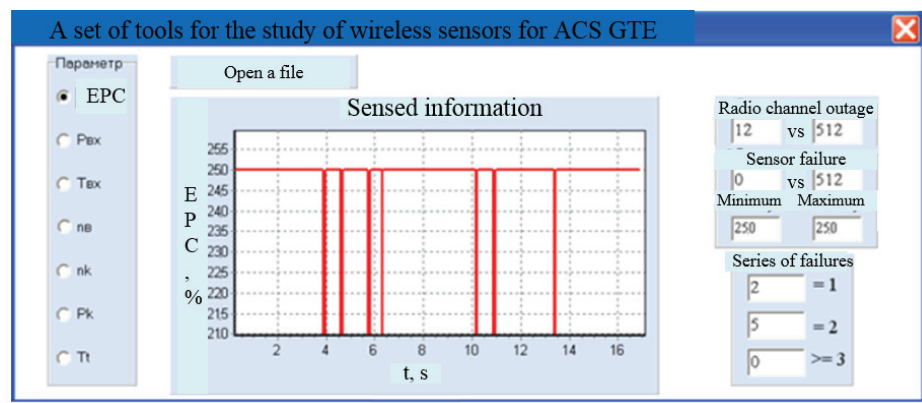

Figure 5. Results of mutual interferences' studies when two Bluetooth systems are operating simultaneously on board aircraft

Thus, Bluetooth data transmission technology is not very effective in terms of ensuring interference immunity and reliability of the information transmitted under the conditions of its application on board aircraft.

Let us consider ultra-wideband short-range transmission technologies that have low power consumption and high interference immunity, and evaluate the possibility of optimal operation on board aircraft.

The operating principle of ultra-wideband short-range transmission radio systems is based on information exchange using pulses of very short duration, which have a very wide spectrum of about ten gigahertz, respectively.

The key features of this technology are:

- high data transfer rate (up to $1.3 \mathrm{Gbit} / \mathrm{s}$ );

- high energy efficiency;

- relative simplicity of modern implementation;

- low ost of systems;

- very low power consumption;

- ex remely low spectral power density $(-40 \ldots-50 \mathrm{dBm} /$ $\mathrm{MHz}$ ), which provides good transmission secrecy;

- echnical simplicity of hardware implementation of receiving and transmitting devices;

- short range - up to ten meters [6].

Ultra-wideband short-range transmission systems provide a high level of electromagnetic compatibility when operating in conjunction with existing communication systems. This is facilitated by the low level of signals, the use of noiseless coding, and the noise-like structure of ultra-wideband short-range transmission radio systems' signals (Figure 6).

Having considered the main mechanisms of UWB (Ultra Wide Band) technology operation and described its main advantages, we will assess the possibility of its optimal functioning on board aircraft.

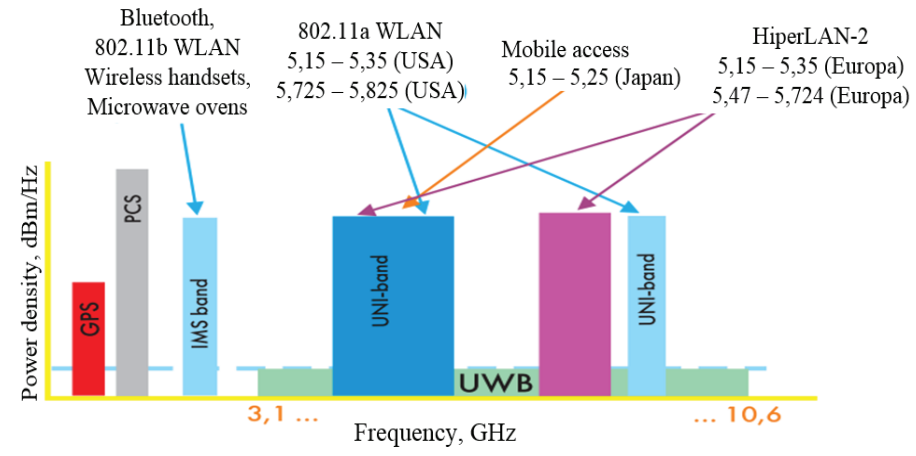

Figure 6. Ratio of frequency bands of known technologies and ultrawideband short-range transmission technologies

In accordance with the standard «Electromagnetic compatibility of technical equipment. Methodology for the achievement of the functional safety of technical equipment with regard to electromagnetic disturbance» of 2007 [7], as well as works [8] and [9], the evaluation of external and internal electromagnetic factors' influence includes consideration of the following issues:

- roviding intra-system and inter-system electromagnetic compatibility;

- ground loops and circuits;

- metallization;

- ightning discharges;

- oc urrence of electrostatic discharges (also during precipitation);

- nfluence of an ultra-short electromagnetic pulse (shortduration pulse interference);

- rad ation level monitoring;

- threats of electro agnetic irradiation of weapons, fuel, and personnel;

- appearance of high-intensity electromagnetic fields [7, 8, 9].

Given that information transmission in UWB technology is carried out using ultra short pulses, it is advisable to consider the effect of ultra-wideband electromagnetic pulses to assess the possibility of its application on board aircraft. Those ultrawideband electromagnetic pulses penetrate an aircraft cabin from outside as a result of aircraft fuselage contact with lightning discharges, as well as areas of high concentration of ions in the airspace.

The standard [7] considers powerful electromagnetic effects of artificial origin with a peak electric field strength of $100 \mathrm{~V} / \mathrm{m}$ in the frequency range from $200 \mathrm{MHz}$ to $5 \mathrm{GHz}$. In particular, the influence of an ultra-wideband electromagnetic pulse is considered.

To assess the potential impact of an ultra-short electromagnetic pulse, it is necessary and sufficient to perform a spectral analysis (to determine the areas of frequency overlap) of desired information signal and interference pulse at the receiving point. Figure 7 schematically shows the spectra of an ultra-wideband, wideband, narrow-band radio signals, as well as an ultra-short electromagnetic pulse. 


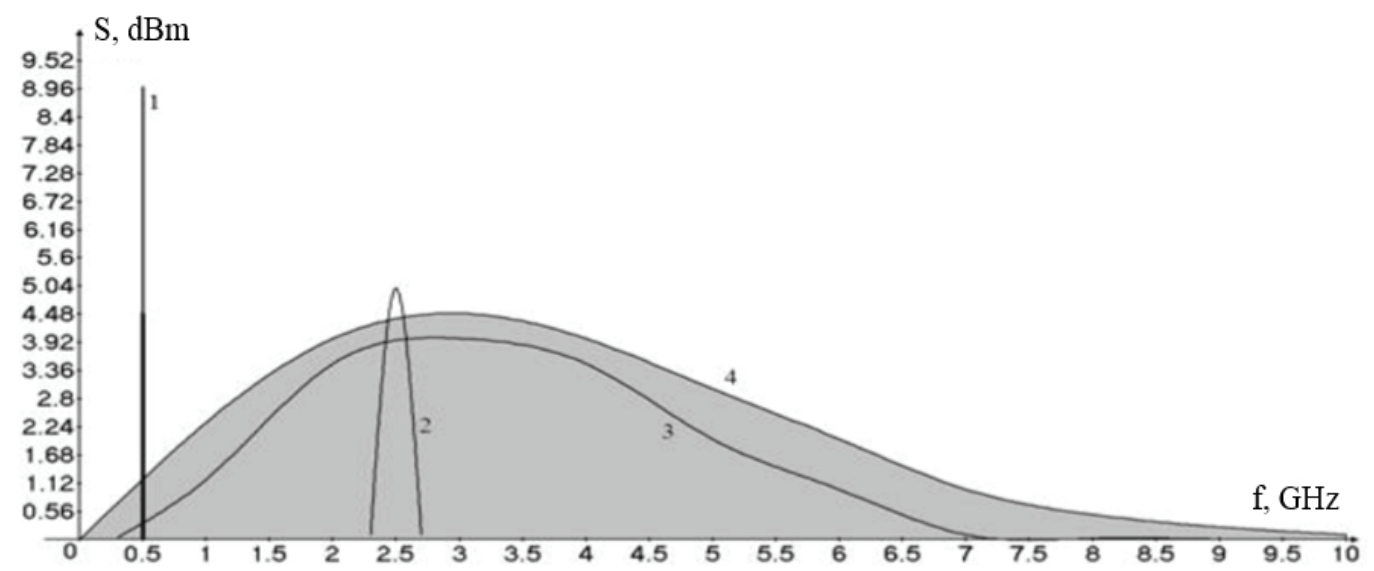

Figure 7. Spectral representation of signals: 1- narrow-band signal; 2 - wideband signal; 3 - ultra-wideband signal, 4 - ultra-short electromagnetic pulse

The presence of a very wide frequency band (up to $10 \mathrm{GHz}$ ) in which there is a relatively constant level of spectral power density of an ultrashort electromagnetic pulse leads to the fact that it has different effects on communication systems with the same energy characteristics. Comparing the spectra allows us to draw a conclusion about the following degrees of influence in descending order:

- UWB radio communication;

- $\mathrm{W}$ deband radio communication;

- na row-band communication system [10].

It is also important to consider the overlap in the temporary area in addition to the spectral one. If the pulse-repetition frequency of ultra-wideband interference pulses is lower than the frequency of the information modulated signal, the effect will be less significant than with a comparable or higher frequency of interference pulses' repetition. Moreover, the cost of UWB signal transmitter receiver modules is quite high, and a sufficiently wide range of operation from 3.1 to $10.6 \mathrm{GHz}$ leads to mutual effects on such aircraft systems as a radio altimeter, a microwave landing aid system, and a meteorological radar station [10]

Thus, having considered the possibility of applying radio frequency wireless technologies for data transmission in medical operational monitoring on board aircraft, we witnessed their low resistance to the effects of complex interference conditions. In order to select a transmission technology, it is necessary to turn our focus towards wireless transmission technologies with the use of optical range and being free of all kinds of radio frequency interference. As such, we will consider Infra red Data Assotiation (IrDA) technology.

Infrared Data Association (IrDA) is a family of standards that regulate the operation of physical and logical data transmission protocols that use infrared band light waves as a carrier [11].

The IrDA protocol allows two devices to connect to each other without a cable using infrared radiation in the range of $850-900 \mathrm{~nm}$. IrDA uses a light-emitting diode with a peak spectral power density as an emitter at a wavelength of $880 \mathrm{~nm}$. The light-emitting diode emits an effective cone-shaped radiation with an angle of about 30 degrees. The IrDA receiver uses PIN diodes that provide reception of infrared radiation in a cone with an angle at the vertex of 15 degrees (Figure 8) [12].

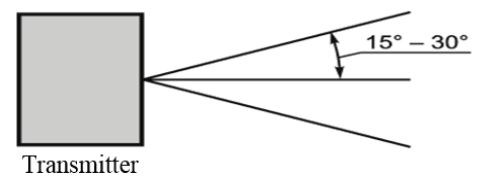

When using standard power, the guaranteed distance between the transmitter and receiver is from 0 to $1 \mathrm{~m}$

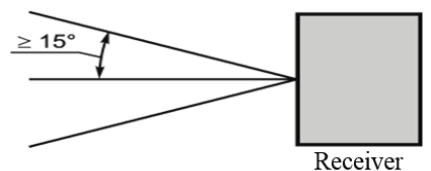

Figure 8. Angle of view and distance for the physical IrDA level

Thus, IrDA technology, which uses the infrared range of light waves as a transmission medium, has good data transfer rate (depending on the specification up to $4 \mathrm{Mbit} / \mathrm{s}$ ), and is not affected by radio frequency interference, which makes it the most applicable for use on board aircraft as compared to the technologies discussed above.

\section{Development of a wireless data transmission network}

It was decided to use a laser instead of a light-emitting diode as a source of data transmission for medical operational monitoring. Laser radiation has the following advantages in comparison with led radiation:

- output power of laser optical radiation is ten times as much as the output power of led optical radiation;

- spec ral band of radiation for conventional LEDs is relatively wide (20-50 $\mathrm{nm}$ ), and for lasers the radiation is monochromatic: the width of spectral band is $0.1-0.4 \mathrm{~nm}$ for a monomode laser and $1-3 \mathrm{~nm}$ for a multimode laser, respectively, and spectral intensity in this band is much higher as compared to led radiation (Figure 9);

- due to a much smaller spectral band of radiation, the effect of interference on the transmitted optical signal of a laser from natural and artificial sources will be less than on the led one (minimizing interference);

- operation speed ( convers on time of an electrical signal to an optical signal ) for laser sources is $0.15 \mathrm{~ns}$, whereas for LEDs it is approximately 3-5 ns;

- va ue of laser radiation modulation frequency can reach 2.5 $\mathrm{GHz}$, for LEDs - $700 \mathrm{MHz}$ [13]. 


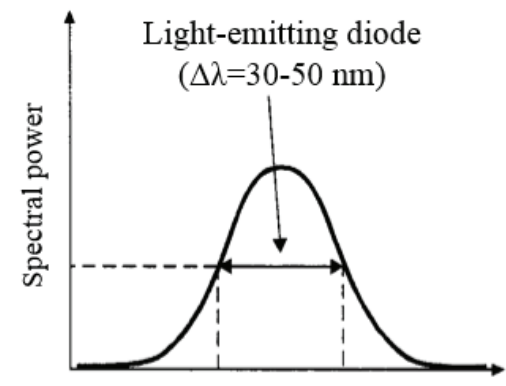

a)

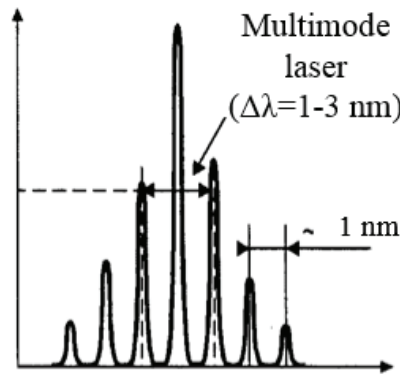

b)
Wavelength, nm

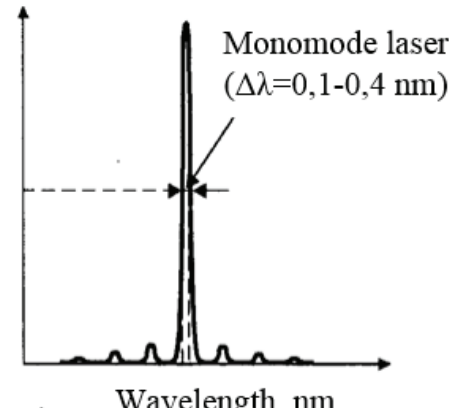

c)

Figure 9. Spectral characteristics of optical radiation: $\mathrm{a}$ - led radiation; $\mathrm{b}$ - multimode laser radiation; $\mathrm{c}$ - monomode laser radiation

Next, you should focus on choosing the type of laser. Currently, the most common are semiconductor lasers, which have a number of advantages over other types of lasers:

- wide range of generation wavelengths (0.3-30 microns);

- ow power consumption;

- direct conversion of electrical energy to optical energy with high efficiency (more than 60\%);

- rap dity;

- s mplicity of modulation processes;

$-\mathrm{s}$ ooth adjustment of generation wavelengths;

- ability to function effectively at room and higher temperatures;

- easy integration of modern laser designs into integrated circuits;

- h gh strength;

- high reliability (the resource of semiconductor lasers reaches 100,000 hours);

- $\mathrm{s}$ all dimensions, low weight, compactness;

- low price [14].

The main advantage that allows semiconductor lasers to be used as sources of data transmission on board aircraft is that they are small in weight and low in power consumption.

It should be noted that one of the most significant disadvantages of semiconductor lasers is low output power. However, this disadvantage is not critical in relation to the possibility of data transmission in the system of medical operational monitoring, since the transmission distance is very small (less than $1 \mathrm{~m}$ ).

A laser based on the $\mathrm{InGaAsP}$ heterostructure with radiation at a wavelength of 1.55 microns was selected as a semiconductor laser for operation in the medical operational monitoring system. We should say that the requirements for the energy component and, consequently, for the power of the laser emitter pumping sources in this spectral region are significantly reduced. Radiation at a wavelength of 1.55 microns is characterized by a smaller amount of scattering and absorption and is absolutely safe for the eyes of an operator, meeting the necessary condition for the introduction and operation of many optical systems.

The technical characteristics of this laser are shown in Table 2.

For now, the domestic optoelectronic industry has developed optical radiation receivers in a wide spectral range (from ultraviolet to deep infrared), operating in the range of reception speeds of about $2.5 \mathrm{Gbit} / \mathrm{s}$. The p-i-n photodiode was selected as the receiving module with the following characteristics as shown in Table 3 .
Table 2

Technical characteristics of a semiconductor laser

\begin{tabular}{|l|c|}
\hline Characteristic, units of measure & Unit value \\
\hline Radiated power, $\mathrm{mW}$ & $1-10$ \\
\hline Wavelength, microns & 1,55 \\
\hline Line width, $\mathrm{nm}$ & 3 \\
\hline Threshold current, $\mathrm{mA}$ & 15 \\
\hline Operating current, $\mathrm{mA}$ & 30 \\
\hline Operating voltage, $\mathrm{V}$ & 2 \\
\hline The feedback photocurrent, $\mu \mathrm{A}$ & 40 \\
\hline Operating temperature range, ${ }^{\circ} \mathrm{C}$ & $\begin{array}{c}\text { from }-40 \text { to }+50 \\
(+25 \text { nominal value })\end{array}$ \\
\hline
\end{tabular}

Table 3

Characteristics of the receiving photodiode

\begin{tabular}{|l|c|}
\hline Characteristic, units of measure & Unit value \\
\hline Wavelength, microns & $1,2-1,6$ \\
\hline Dynamic range, dbm & from -39 to +3 \\
\hline Photodetector sensitivity, A/W & 0,9 \\
\hline Supply voltage, $\mathrm{V}$ & 5 \\
\hline Operating temperature range, ${ }^{0} \mathrm{C}$ & $\begin{array}{c}\text { from }-40 \text { to }+70 \\
(+25 \text { nominal value })\end{array}$ \\
\hline Photodetector capacity, $\mathrm{pF}$ & 0,7 \\
\hline Dark current, $\mathrm{nA}$ & 2 \\
\hline $\begin{array}{l}\text { Inherent noise power spectral } \\
\text { density, } \mathrm{W} \cdot \mathrm{Hz}^{-1 / 2}\end{array}$ & $3 \cdot 10^{-15}$ \\
\hline
\end{tabular}

It should be emphasized that these semiconductor devices have a very large range of operating temperatures, which allows us to talk about the system availability under the conditions of aircraft cabin depressurization.

A block diagram of organizing data transmission from the pilot's physiological parameters processing unit to the data collection unit based on optical infrared radiation in medical operational monitoring system is shown in Figure 10.

The byte to be transmitted is sent to the transmitting module block, where the start and stop bits are added to it. The character is passed sequentially, starting with the lowest bit value. The encoded octet includes a start bit (a logical zero represented by the presence of an optical pulse), followed by 8 data bits, and a stop bit (a logical unit represented by the absence of an optical pulse). 


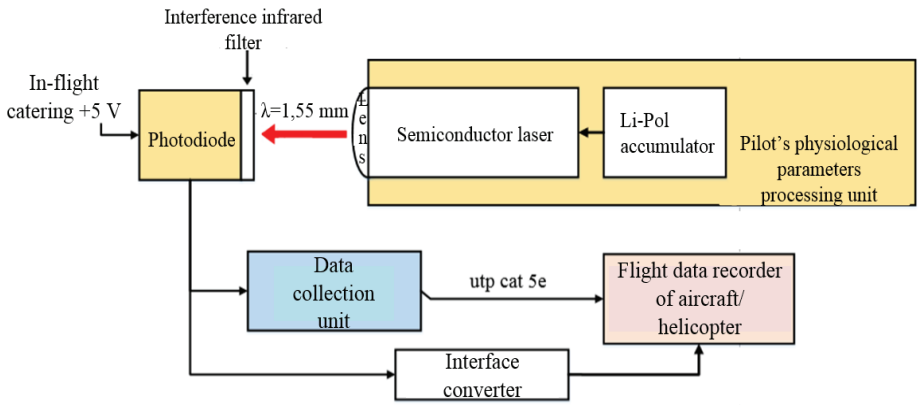

Figure 10. A variant of organizing a wireless data transmission network from the pilot's physiological parameters processing unit to the data collection unit

Each bit containing a logical zero is represented by an optical pulse with a maximum duration equal to $3 / 16$ of bit duration (Figure 11).

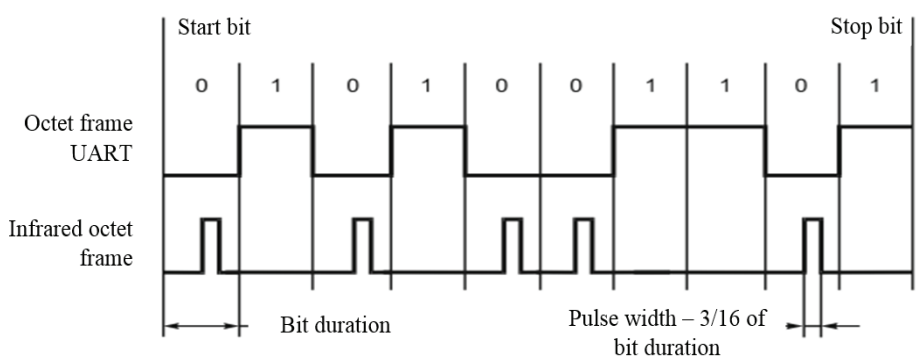

Figure 11. 3/16 data encoding for IrDA

When the bit encoding is complete, the transmitted data is modulated. In semiconductor lasers, radiation modulation is carried out by modulating pump current. In the diagram shown in Figure 11, the infrared pulses start in the middle of each transmitted bit's period, which is the optimal time for the encoder to encode the output from data bus $[13,14]$.

The transmitted pulses are sent to a photodiode that converts light pulses into current pulses, which are amplified and compared with the threshold level for conversion to logical levels (" 0 " if there is light pulse, " 1 " if there is no pulse) in the data collection unit.

The photodiode that receives the infrared signal is fixed to the wall of the cockpit opposite the pilot's chest as much as possible to maintain radiation direction. Since the pilot is mobile during the flight and radiation direction conditions may not be met at certain times, a semiconductor laser is equipped with a thin scattering lens that increases the area of possible infrared radiation reception. As it was mentioned above, laser radiation is not affected by various types of radio frequency interference, but the photodiode input, in addition to the "wanted" infrared radiation will get natural light, as well as radiation of artificial origin. To eliminate these side-effects, a multi-layer interference filter is placed in front of the photodiode. If a fault occurs in the data collection unit, the signal from the photodiode is transmitted to the "black box", bypassing the faulty unit.

\section{Evaluation of interference immunity level and methods for its improvement}

It is possible to estimate interference immunity of the proposed transmission network based on determining the immunity value and bandwidth capacity of the wireless communication channel according to the Shannon - Hartley theorem (1):

$$
C=B \cdot \log _{2}\left(1+\frac{S}{N}\right),
$$

Where $C$ - channel bandwidth capacity, bit/ s; $B$ - channel bandwidth, Hz; $S$ - total signal power, $W ; N$ - total noise power, $\mathrm{W}$ [15].

The photodiode input receives a signal that is a mixture of encoded wanted data, and continuous random data that is an interference signal. Further, we shall calculate data transmission channel bandwidth.

$$
B=\frac{v}{\lambda}=\frac{3 \cdot 10^{8}}{1,55 \cdot 10^{-6}}=1,935 \cdot 10^{14} \mathrm{~Hz},
$$

After that, you need to determine a signal-to-noise ratio. A semiconductor laser is the source of a signal. Signal power $S$ is light power in the corresponding radiation stream estimated by the light stream $\Phi[16]$.

The main sources of interference and noise in wireless optical transmission networks are natural and artificial lighting, luminosity (reflection of light by surfaces, also due to light interference). Signal strength can be estimated in watts, while the power of noise generated by ambient light is unlikely to be represented in watts. That is why the effect of noise can be fairly estimated by illumination level $E$ [16].

Illumination is directly proportional to light intensity of the source and inversely proportional to square of the distance to the illuminated surface. If there is an oblique incidence of rays relative to the illuminated surface, illumination volume decreases in proportion to angle cosine of incidence of rays. Thus, illumination $E$ from a point source can be calculated from expression (2) [16]:

$$
E=\frac{I}{r^{2}} \cdot \cos (i)
$$

where $I$ - light intensity, $\mathrm{kJ} ; r$ - distance to light source, $m$; $i$ - angle of incidence of light rays relative to the surface, rad.

Noise power $N$ is defined as the ambient illumination $E_{O K P}$, which contains not only natural $E_{E C T}$ and artificial $E_{И С К}$ illumination, but also the total luminosity of objects, which we will call the reflected illumination EOTP, taking into account multipathing due to light scattering on the surfaces of an aircraft cabin and objects in it (3) [15]:

$$
\begin{aligned}
& N=E_{\text {ОКР }}=E_{E C T}+E_{\text {ИСК }}+E_{\text {ОТР }}= \\
& =\frac{I_{E C T}}{r_{E C T}^{2}} \cos \left(i_{E C T}\right)+\frac{I_{\text {ИС }}}{r_{\text {ИСК }}^{2}} \cos \left(i_{\text {ИСК }}\right)+\frac{I_{\text {OTP }}}{r_{\text {OTP }}^{2}} \cos \left(i_{\text {ОТР }}\right)
\end{aligned}
$$

In the daytime, when flying at medium altitudes, natural light is sufficient for normal operation in the cockpit. In some cases (for example, when flying on a bright sunny day over an area covered with snow), one even has to reduce the intensity of lighting by using protective curtains and light filters. During night flights, it is necessary to use artificial lighting. 
The illumination of crew members' work places should be sufficient for easy reading of the instruments, inscriptions on stencils and flight maps. However, it should not interfere with visual observation of the surrounding situation. The normalized illumination value of a cockpit is 350 Lux.

Thus, putting all the data in formula (1), we obtain (4):

$$
C=B \cdot \log _{2}\left(1+\frac{I \cdot \cos (i)}{\left(E_{E C T}+E_{\text {UCK }}+E_{\text {OTP }}\right) \cdot r^{2}}\right) .
$$

Interference immunity of the wireless optical data transmission channel can be calculated by formula (5):

$$
A=10 \cdot \log _{10}\left(\frac{S_{\min }}{N}\right)=10 \cdot \log _{10}\left(1+\frac{I \cdot \cos (i)}{\left(E_{E C T}+E_{\text {ИСК }}+E_{\text {OTP }}\right) \cdot r^{2}}\right)
$$

where $A$ - interference immunity level of optical communication channel, dB; $S_{\text {min }}$ - minimum luminous power, $1 \mathrm{~m}$.

High value $A$ means that the effect of interference on the signal is minimal [15].

In order to reduce the denominator component $E_{E C T}+E_{\text {ИСК }}+E_{\text {OTP }}$ to the minimum value and obtain a higher value of interference immunity, the proposed variant of wireless data transmission based on laser infrared radiation provides for the use of an interference infrared filter.

An interference filter consists of several components. Each component, in its turn, is made from a set of thin films with different substances sprayed on them and is called a "system". These systems, depending on their purpose, are divided into the main ones (which form the filter pass band ) and additional ones, which are designed to eliminate the secondary band passes of the main system (in this case, to eliminate the ingress of natural light and artificial radiation to the photodiode).

In the middle region of the infrared spectrum, interference filters are made from systems of thin films produced by vacuum deposition of evaporated materials. Multilayer interference systems consisting of alternating layers with high $(\mathrm{H})$ and low $(\mathrm{L})$ refractive indices and having an optical thickness equal to a quarter of wavelength $\lambda_{0}$ are called quarter-wave systems. This implies wavelength for which the interference extremum of the first order is available. Multilayer interference systems obtained in this way can be divided into three groups according to their spectral characteristics: narrow-band, band-pass, and cut-off systems. In this paper, narrow-band filters are considered, therefore we shall focus on them in more detail.

Using narrow-band filters, one can select spectral bands of different widths, ranging from a few angstroms to tenths of a micron.

Structurally, a narrow-band filter consists of several components. The main component is two quarter-wave mirror systems separated by a layer with an optical thickness $n l=m \frac{\lambda_{0}}{2}$ (where $m$ is the order of filter interference). Higher-order narrow-band systems, cutting-off systems, or absorption-type filters are used as additional components that serve to suppress secondary band passes.

The typical spectral characteristic of a multilayer system of narrow-band filter is shown in Figure 12, where $\lambda_{\max }$ is wavelength of maximum pass band; $T_{\max }$ - maximum pass band; $\delta \lambda_{0,5}$ - pass bandwidth available for level $0,5 T_{\max }, \delta \lambda_{0,1}$ - pass bandwidth at the level of ten percent pass, $T_{\text {min }}^{\kappa}$ and $T_{\text {min }}^{\partial}$ - values of minimum pass band with short-wave and long-wave sides of the main pass band.

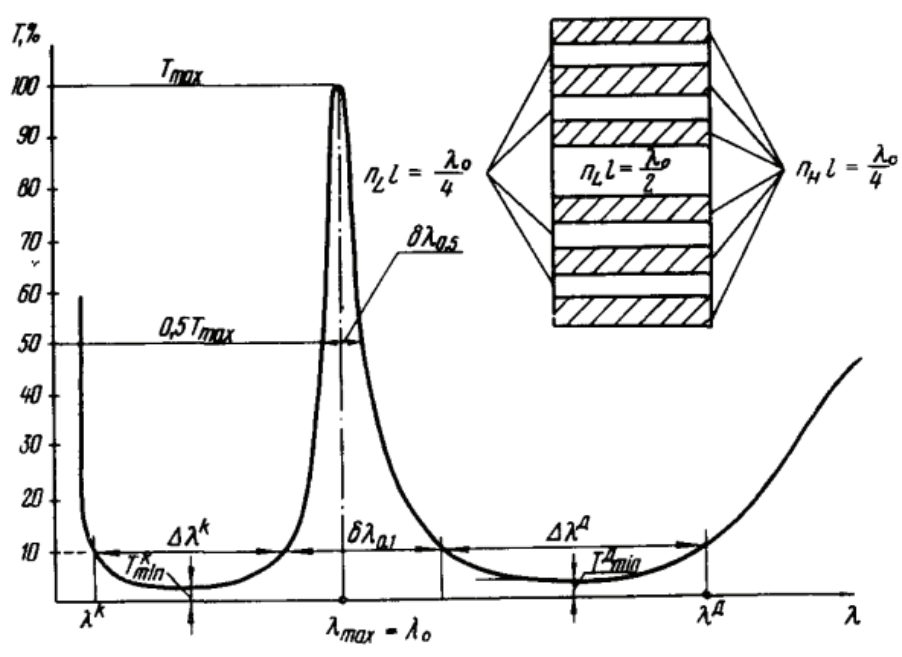

Figure 12. Spectral characteristic and structure of a narrow-band multi-layer interference filter

Based upon the spectral characteristics of a narrow-band system, it can be seen that the main multi-layer system that forms a transparency band has secondary bandwidth, which is usually eliminated by adding the main system to other types of systems. In this connection, it is useful to introduce some additional notation: $\Delta \lambda^{\kappa}, \Delta \lambda^{\partial}$ is the spectral width of low pass $(T<10 \%)$ with short-wave and long-wave sides of the main pass band, $\lambda^{\kappa}$ and $\lambda^{\partial}$ - wavelengths of short-wave and long-wave upswing of the secondary bandwidths corresponding to ten percent pass from $T_{\max }$. These parameters are important from the point of view of designing narrow-band infrared filters, since they are the starting values for selecting components that eliminate secondary transparency bands of the system [17].

The interference filter used is recommended to be made from gallium antimonide GaSb films. It is a chemical compound of gallium and antimony. This material has a high refractive index, inertness to many aggressive media, very good resistance to abrasion, low susceptibility to mechanical influences. The above mentioned chemical compound has a fairly narrow bandwidth of 1.25-2.1 microns, the middle of which falls on the wavelength of laser radiation of 1.55 microns. The narrow bandness of the material used in the filter will minimize the need to use a secondary bandwidth suppression system, which will simplify and reduce the cost of the filter design. It is also worth noting that this material is resistant to humidity, and temperature changes practically do not affect its characteristics. 


\section{Results and discussion}

In the present paper, a variant of organizing a wireless network for transmitting physiological indicators of the pilot's health based on mid-infrared laser radiation (IrDA technology) has been developed. The selected variant is not affected by radio frequency interference, which makes it the most applicable for use on board aircraft. The paper proposes to use a semiconductor laser based on InGaAsP heterostructure with monochromatic radiation at a wavelength of 1.55 microns, high output power of optical radiation, and narrow (1-3 nm) spectral band width, which minimizes the effect of interference from natural and artificial light sources on the transmitted optical signal. The choice of radiation wavelength is due to the lower amount of scattering and absorption, as well as safety for the operator's eyes. Radiation direction is maintained by equipping the laser with a thin scattering lens that increases the possible reception area. Eliminating side radiation is performed using a multi-layer interference filter made of GaSb gallium antimonide films which has a high refractive index, inertness to aggressive media, high wear resistance, and narrow bandwidth (1.25 - 2.1 microns). The evaluation of interference immunity of the wireless optical transmission line showed that the use of such a filter does allow you to increase a signal-to-noise ratio at the input of photodiode. The pass bandwidth was $1,935 \cdot 10^{14} \mathrm{~Hz}$. A backup line is provided. In case of data collection unit malfunction, the signal from the photodiode is transmitted to an aircraft's flight data recorder.

\section{References}

1. Mukhin I.E., Seleznev S.L., Koptev D.S. (2017). Directions and practical results of the creation of methods and means of diagnosis and prognosis state of the aviation complex "man - machine". Bulletin of the South-West. state un-that. Series. Management, computer engineering, computer science. Medical instrumentation. Vol. 7, No. 3 (24), pp. 46-57.

2. Anikin A.A. (2017). Overview of modern technologies for wireless data transmission in the ISM frequency bands (Bluetooth, ZigBee, Wi-Fi) and 434/868 MUc. Wireless Technologies. No. 4, pp. 6-12.

3. Sardin I.V. (2016). The problems of the functioning of wireless Bluetooth devices and IEEE 802.11 in the unlicensed frequency range of ISM $2.4 \mathrm{GHz}$ and how to solve them. Wireless Technologies. No. 3, pp. 43-47.
4. Artyushenko V.M. (2010). Analysis of wireless data exchange technologies in life support systems for industrial and office premises. Electrotechnical complexes and systems. No. 2, pp. 18-24.

5. Gurevich O.S., Kesselman M.G., Trofimov A.S., Chernyshov V.I. (2011). Modern wireless technologies: problems of application on an aircraft board. Transactions of MAI. No. 94, pp. 2-20.

6. Nosov V.I., Kalinin V.O. (2017). Study of methods for increasing noise immunity of short-pulse ultra-wideband radio communication systems. Novosibirsk: Publishing House of the Siberian State. University of Telecommunications and Informatics. $244 \mathrm{p}$.

7. Electromagnetic compatibility. Methodology for ensuring the functional safety of technical equipment with respect to electromagnetic interference. GOST R 51317.1.2 - 2007. Introduction. 2007 - 12 - 27 Moscow: Publishing house of standards, 2007. 51 p.

8. Myrova L.O., Popov V.D., Verkhoturov V.I. (1993). Analysis of the resistance of communication systems to radiation. Moscow: Radio and Communications. $268 \mathrm{p}$.

9. Shmyryov V.F., Elk A.V. (2011). Modern requirements and approaches to the protection of electronic systems from electromagnetic effects of high-intensity fields, lightning, etc., as well as ensuring the airworthiness standards of aircraft in terms of increasing the efficiency of their means of protection during operation. Open information and computer integrated technologies. No. 49, pp. 51-76.

10. Pimenov P.N. (2015). Comparative analysis of the influence of an ultrashort electromagnetic pulse on narrow-band, broadband, ultrawideband radio communication systems. EMC Technologies. No. 1 (52), pp. 13-16.

11. Dmitriev A.L. (2017). Optical information transmission systems. SPb.: Publishing house - in SPbSUITMO. 96 p.

12. Interaction of medical devices at the treatment site. Transport profile. Infrared communication channel. GOST R 54481 - 2011. Introduction. $2011-10-25$ - Moscow: Publishing house of standards, 2012. $54 \mathrm{p}$.

13. Baranov V.N., Kuzyakov O.N., Bochkov M.S. et al. (2012). Laser and LED medical devices and systems. Tyumen: Publishing house at Tsogu. $176 \mathrm{p}$.

14. Dmitriev A.L. (2006). Semiconductor light sources for information transmission and processing systems. SPb.: Publishing house in SPbSUITMO. $158 \mathrm{p}$.

15. Nevolin D.G., Petrus I.P. (2017). Interference immunity of wireless optical local data networks based on visible light emitting diodes. Yekaterinburg: UrGUPS. $144 \mathrm{p}$.

16. Petrus I.P. (2016). Estimation of the throughput of a wireless optical communication channel based on visible light emitting diodes. T-Comm. No. 3 (10), pp. 56-62.

17. Borisevich N.A., Vereshchagin V.G., Validov M.A. (1971). Infrared filters. Minsk: Science and technology. 228 p. 


\title{
ВАРИАНТ ОРГАНИЗАЦИИ БЕСПРОВОДНОЙ СЕТИ ПЕРЕДАЧИ ФИЗИОЛОГИЧЕСКИХ ПОКАЗАТЕЛЕЙ ЗДОРОВЬЯ ПИЛОТА НА БОРТУ ВОЗДУШНОГО СУДНА НА ОСНОВЕ ЛАЗЕРНОГО ИЗЛУЧЕНИЯ СРЕДНЕГО ИНФРАКРАСНОГО ДИАПАЗОНА
}

\author{
Коптев Дмитрий Сергеевич, Юго-Западный государственный университет" (ФГБОУ ВО "ЮЗГУ"), г. Курск, Россия, \\ d.s.koptev@mail.ru
}

\section{Аннотация}

Согласно стратегии развития авиастроения вплоть до 2023 г., основные усилия авиационной промышленности направлены создание высокоскоростных и маневренных самолетов за счёт увеличения мощности двигательных агрегатов, реализации сложных систем управления полетом, навигации, повышения характеристик технического оснащения. Однако, физиологические возможности оператора воздушного судна (пилота) начинают отставать от технологических возможностей новейшей авиационной техники в плане эффективного и оперативного управления ею, выполнения боевых задач и переносимости существенных перегрузок. Более 70\% авиационных происшествий связано именно с лётной деятельностью экипажей, треть которых обусловлена нарушением функционального состояния пилота, вследствие воздействия экстремальных факторов полёта. Система оперативного медицинского контроля (СОМК) предназначена для регистрации физиологических показателей здоровья пилота.

Ключевые слова: система оперативного медицинского контроля, физиологические показатели здоровья пилота, беспроводная передача данных, оптическое излучение, сверхширокополосный сигнал, электромагнитная помеха, помехоустойчивость, полупроводниковый лазер, спектр сигнала.

\section{Литература}

І. Мухин И.Е., Селезнев С.Л., Коптев Д.С. Направления и практические результаты создания методов и средств диагностики и прогностики состояния авиационного комплекса "человек - машина" // Известия Юго-Зап. гос. ун-та. Серия. Управление, вычислительная техника, информатика. Медицинское приборостроение. 2017. Т. 7, № 3(24). С. 46-57.

2. Аникин А.А. Обзор современных технологий беспроводной передачи данных в частотных диапазонах ISM (Bluetooth, ZigBee, Wi-Fi) и 434/868 МUц // Беспроводные технологии. 2017. № 4. С. 6-12.

3. Сардин И.В. Проблемы функционирования беспроводных устройств Bluetooth и IEEE 802.II в нелицензируемом диапазоне частот ISM 2,4 ГГц и пути их решения // Беспроводные технологии. 2016. № 3. С. 43-47.

4. Артюшенко В.М. Анализ беспроводных технологий обмена данными в системах автоматизации жизнеобеспечения производственных и офисных помещений // Электротехнические комплексы и системы. 2010. № 2. С. 18-24.

5. Гуревич О.С., Кессельман М.Г., Трофимов А.С., Чернышов В.И. Современные беспроводные технологии: проблемы применения на авиационном борту // Труды МАИ. 20II. № 94. С. 2-20.

6. Носов В.И., Калинин В.О. Исследование методов повышения помехоустойчивости короткоимпульсных сверхширокополосных систем радиосвязи. монография. Новосибирск: Изд-во Сибирского гос. ун-та телекоммуникаций и информатики, 2017. 244 с.

7. Совместимость технических средств электромагнитная. Методология обеспечения функциональной безопасности технических средств в отношении электромагнитных помех [Текст]: ГОСТ Р 5 І3І7.І.2 - 2007. - Введ. 2007 - 12 - 27. М.: Изд-во стандартов, 2007. 5 І с.

8. Мырова Л.О., В.Д. Попов, Верхотуров В.И. Анализ стойкости систем связи к воздействию излучения: учеб. для вузов. М.: Радио и связь, І993. 268 c.

9. Шмырёв В.Ф., Лось А.В. Современные требования и подходы к защите электронных систем от электромагнитных воздействий полей высокой интенсивности, молнии и др., а также обеспечению норм летной годности самолетов в части повышения эффективности средств их защиты в процессе эксплуатации // Открытые информационные и компьютерные интегрированные технологии. 20I I. № 49. С. 5I-76.

10. Пименов П.Н. Сравнительный анализ влияния сверхкороткого электромагнитного импульса на узкополосные, широкополосные, сверхширокополосные системы радиосвязи // Технологии ЭМС. 2015. № I (52). С. I3-16.

ІІ. Дмитриев А.Л. Оптические системы передачи информации: учеб. пособие. СПб.: Изд-во СПбГУИТМО. 2017.96 с.

12. Взаимодействие медицинских приборов на месте лечения. Транспортный профиль. Инфракрасный канал связи [Текст]: ГОСТ Р 5448 I - 20II. - Введ. 2011 - 10 - 25. М.: Изд-во стандартов, 2012. 54 с.

13. Баранов В.Н., Кузяков О.Н., Бочков М.С. и др. Лазерные и светодиодные медицинские приборы и системы: учеб. пособие. Тюмень: Изд-во ТюмГНГУ. 20I2. 176 с.

14. Дмитриев А.Л. Полупроводниковые источники света для систем передачи и обработки информации: учеб. пособие. СПб.: Изд-во СПбГУИТМО. 2006. $158 \mathrm{c.}$

І 5. Неволин Д.Г., Петрусь И.П. Помехоустойчивость беспроводных оптических локальных сетей передачи данных на базе светодиодов видимого излучения: монография. Екатеринбург: УрГУПС, 2017. 144 с.

16. Петрусь И.П. Оценка пропускной способности беспроводного оптического канала связи на базе светодиодов видимого излучения // Т-Сотт: Телекоммуникации и транспорт. 2016. № 3 (10). С. 56-62.

17. Борисевич Н.А., Верещагин В.Г., Валидов М.А. Инфракрасные фильтры: монография. Минск: Наука и техника, 197І. 228 с.

Информация об авторе:

Коптев Дмитрий Сергеевич, аспирант, федеральное государственное бюджетное образовательное учреждение высшего образования "Юго-Западный государственный университет" (ФГБОУ ВО "ЮЗГУ"), г. Курск, Россия 